\title{
PERAWATAN BEDAH FLAP PERIODONTAL PADA PERIODONTITIS KRONIS: SEBUAH LAPORAN KASUS
}

\author{
Sri Oktawati ${ }^{*}$, Lilies Anggarwati Astuti ${ }^{\star *}$ \\ *) Departement of Periodontics, Faculty of Dentistry, Hasanuddin University \\ ${ }^{\star *}$ Periodontics Residency Program, Faculty of Dentistry, Hasanuddin University \\ Email : liliesanggarwatigauk@yahoo.com.
}

\begin{abstract}
Introduction: Chronic periodontitis is an inflammatory disease in periopdontal tissue. Subgingiva specific organisms are to be responsible for this gingiva inflammatory reaction. Gingiva attachment loss would occurred along with alveolar bone destruction, periodontal pocket formation, pathological migration and mobility of teeth. Case: A 48-year-old male was referred to the Departement of Periodontology RGSM Kandea Makassar. On clinical examination, tooth mobility in relation to teeth $31,32,33,34,41,42,43,44$ was noticed. Chewing difficulty was reported by the patient. There was no routine control by dentists. Methode: Presurgery examination of teeths 31,32,33,34,41,42,43,44 showed mean pocket depths $>5 \mathrm{~mm}$, there was gingiva recession and -3 teeth mobility. The patients was managed by an open flap debridement under local anesthesia. All subgingiva deposits were removed using curettes. The tissue was sutured and periodontal pack was put in place. Result: The patient was recalled after 3 weeks for suture removal and reevaluation. His results shows normal gingiva tissue with good tissue attachment. Teeth mobility was decreased by 01 . Conclusion: This case report emphasizes the importance of routine dental examination for early intervention of chronic periodontitis.
\end{abstract}

Keyword: Chronic Periodontitis, Open Flap Debridement, Curettage.

\section{PENDAHULUAN}

Periodontitis kronis merupakan penyakit peradangan pada jaringan periodontal yang disebabkan terutama oleh bakteri spesifik pada subgingiva yang dapat menimbulkan respon inflamasi gingiva dan berlanjut ke struktur jaringan penyangga gigi yaitu sementum, ligamentum periodontal dan tulang alveolar. Keadaan ini mengakibatkan hilangnya perlekatan gingiva dan terjadinya kerusakan tulang alveolar lebih dalam, pembentukan poket periodontal, migrasi patologis yang menimbulkan diastema dan kegoyangan gigi yang dapat berakibat tanggalnya gigi. Penyebab utama keradangan gingiva pada periodontitis adalah plak bakteri subgingiva meliputi bakteri obligat anaerobic gram negatif seperti Porphyromonas gingivalis, Prevotella intermedia, Bacteriodes forsythus, Fusobacterium nucleatum, 
Selenomonas dan Campylobacter, serta fakultatif anaerob gram negatif seperti

Actinobacillus

actinomycetemcomitans,

Capnocytophaga dan Eikenella corrodens. $^{1}$

Selanjutnya Novak dan rekanrekannya menyatakan bahwa periodontitis kronis ini menyebabkan terjadinya inflamasi di dalam jaringan pendukung gigi, hilangnya perlekatan secara progresif, dan kehilangan tulang. ${ }^{2}$

Kedalaman poket bervariasi dan dapat ditemukan kerusakan tulang dengan pola horisontal atau pun vertikal. $^{2,3,4}$ Kegoyangan gigi terjadi pada kasus-kasus tahap lanjut disertai kehilangan perlekatan dan resorpsi tulang yang sangat luas. ${ }^{2}$

Periodontitis kronis didiagnosa secara klinis dan radiografi. Secara klinis, periodontitis kronis didiagnosa melalui perubahan inflamasi pada gingiva marginal, adanya poket periodontal, dan hilangnya perlekatan klinis. Adapun diagnosa secara radiografinya dibuktikan dengan kehilangan tulang alveolar. ${ }^{2}$

Besarnya destruksi jaringan periodontal pada periodontitis kronis dipengaruhi oleh tingkat kebersihan mulut dan banyaknya plak, dimodifikasi oleh faktor-faktor lain seperti merokok, stress, dan faktor resiko sistemik. $^{3}$

Kerusakan

jaringan periodonsium yang ditimbulkan oleh periodontitis kronis berlangsung lambat. Perawatan penyakit ini biasanya meliputi terapi awal (iniitial therapy) yaitu skeling, kuretase, root planing, instruksi pemeliharaan kebersihan mulut dan kontrol pola makan, terkadang dibutuhkan modulasi host dan khemoterapi, penyesuaian oklusal gigi, splinting atau pergerakan ortodontik yang ringan jika diperlukan. Follow up setelah beberapa minggu atau bulan diperlukan untuk mengevaluasi respon penyakit ini terhadap terapi awal tersebut. Evaluasinya berupa pengecekan kedalaman poket periodontal dan inflamasi gingival, serta mengukur kembali indeks plak dan kalkulus. Hasilnya menentukan keputusan apakah pasien memerlukan terapi bedah (surgical therapy) atau perawatan dilanjutkan ke fase pemeliharaan

(maintenance therapy). ${ }^{2,3,5,6}$

Bedah flep periodontal
merupakan salah satu terapi
perawatan dalam bidang periodonsia dengan tujuan untuk eliminasi plak, kalkulus, jaringan nekrosis dan jaringan granulasi pada kerusakan 
tulang dengan poket sedang sampai dalam, serta penempatan material regeneratif. Dalam prosedr bedah periodontal, gingiva memerlukan evaluasi dan reseksi untuk mendapatkan akses ke permukaan akar dan struktur pendukung tulang. Kompromi estetik pada daerah anterior dapat menjadi konsekuensi serius prosedur bedah periodontal. $^{7}$

Tujuan perawatan periodontitis kronis adalah untuk mengembangkan suatu kondisi jaringan periodonsium sehat dengan status stabil dapat dipertahankan melalui kerjasama antara pasien dan dokter gigi yang merawatnya. ${ }^{2,3,8}$

Kegoyangan gigi merupakan salah satu gejala penyakit periodontal yang ditandai dengan hilangnya perlekatan serta kerusakan tulang vertikal. Kegoyangan dapat disebabkan adanya kerusakan tulang yang mendukung gigi, trauma dari oklusi, dan adanya perluasan peradangan dari gingival ke jaringan pendukung yang lebih dalam serta proses patologik rahang. Menurut Fedi dkk kegoyangan gigi diklasifikasikan menjadi tiga derajat. Derajat 1 yaitu kegoyangan sedikit lebih besar dari normal. Derajat 2 yaitu kegoyangan sekitar $1 \mathrm{~mm}$ dan derajat 3 yaitu kegoyangan $>1 \mathrm{~mm}$ pada segara arah dan/atau gigi dapat ditekan ke arah apikal. ${ }^{1}$

Salah satu cara untuk mengontrol dan menstabilisasi apabila terdapat kegoyangan gigi adalah splinting. Splinting diindikasikan pada keadaan kegoyangan gigi derajat 3 dengan kerusakan tulang berat. Adapun indikasi utama penggunaan splint dalam mengontrol kegoyangan, yaitu imobilisasi kegoyangan yang menyebabkan ketidaknyamanan pasien serta menstabilkan gigi pada tingkat kegoyangan yang makin bertambah. Ditambahkan oleh Strassler dan Brown, splinting juga digunakan untuk mengurangi gangguan oklusal dan fungsi mastikasi. $^{1}$

Splinting dilakukan pada terapi inisial (fase etiotropik) dalam rencana perawatan penyakit periodontal. Tindakan yang dilakukan pada fase pertama adalah pemberian kontrol plak yang meliputi motivasi, edukasi dan instruksi, skeling dan penghalusan akar, splinting dan terapi oklusal, serta pemberian terapi penunjang berupa antimikroba. ${ }^{1}$

Tujuan penulisan laporan kasus ini adalah untuk menunjukkan bahwa perawatan bedah flap periodontal merupakan salah satu alternatif perawatan yang dapat diambil untuk 
kasus periodontitis kronis yang dapat dikombinasikan dengan splint komposit.

\section{Kasus:}

Seorang pasien laki-laki berumur 48 tahun datang ke bagian periodonsia RSGM Kandea Makassar. Pasien datang pada bulan Februari 2014 dengan keluhan utama gigi depan rahang bawah goyang sejak 6 bulan lalu. Gejala ini mulai dirasakan sejak 2 tahun lalu, namun kegoyangan yang semakin parah sekitar 6 bulan lalu. Gusi pada daerah tersebut mudah berdarah pada saat menggosok gigi. Pasien merasa tidak percaya diri dan kurang nyaman dengan keadaan tersebut. Berdasarkan anamnesis, pasien tidak memiliki riwayat penyakit sistemik. Pada pemeriksaan ektra oral tidak terdapat kelainan. Pada pemeriksaan klinis (Gambar 1) terdapat gigi goyang 31,32,33,34,41,42,43,44. Gingiva mudah berdarah saat probing, udem, hiperemi, resesi gingival, terdapat poket gigi 31,32,41,42 sekitar 8-9 mm. Sedangkan gigi $33,34,43,44$ sekitar 5 $\mathrm{mm}$. terdapat edentulous 11,12 dengan pemakaian GTSL (Gigitiruan Sebagian Lepsan) 11. Terdapat kalkulus pada interdental gigi dan lingual gigi sehingga terlihat jelas akar dari gigi tersebut. Oklusi gigi-gigi anterior rahang atas terlihat prematur kontak dengan gigi-gigi anterior rahang bawah. Pasien mengeluh sulit mengunyah. Pasien tidak pernah periksa rutin ke dokter gigi. Pada pemeriksaan radiografis (Gambar 2) terlihat adanya kerusakan tulang alveolar arah vertikal pada gigi $31,32,41,42$.

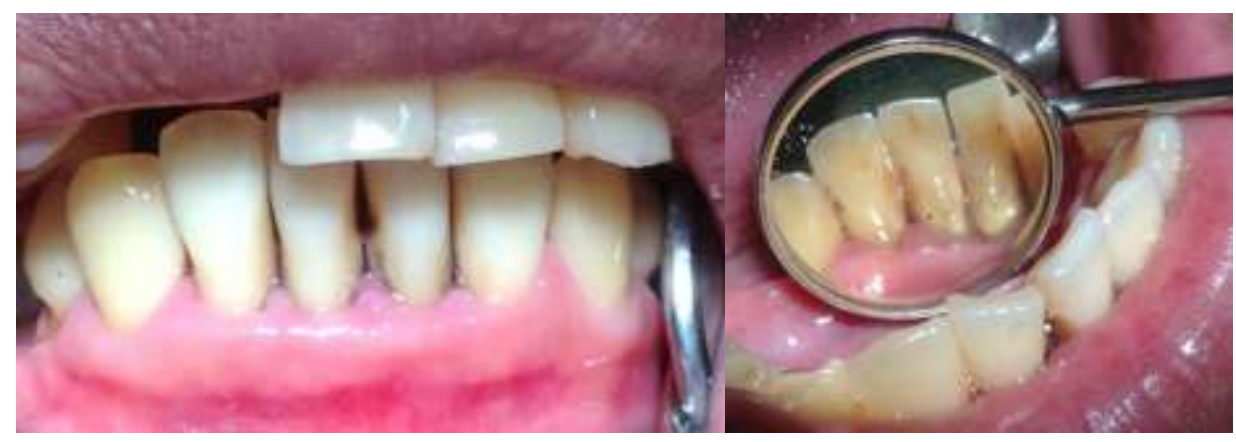

Gambar 1. Pemeriksaan klinis 


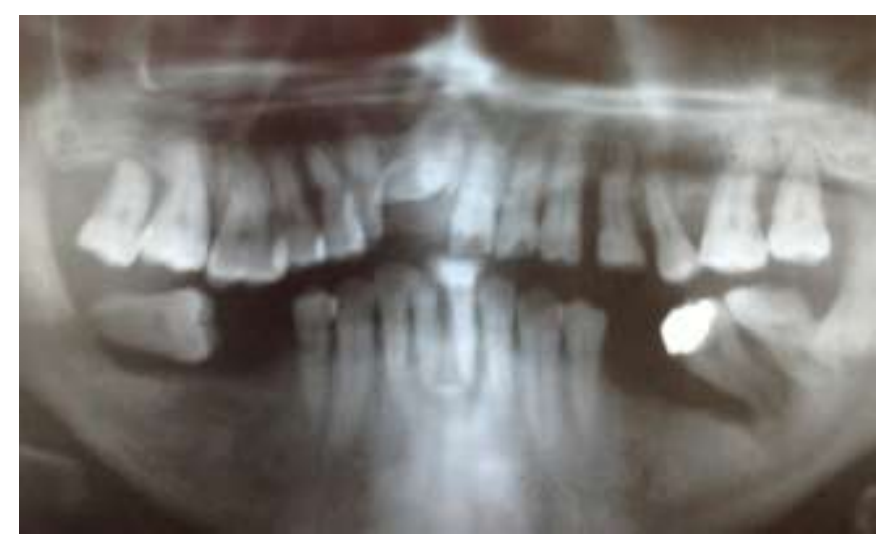

Gambar 2. Pemeriksaan radiografis

Diagnosa klinis adalah periodontitis kronis pada gigi $31,32,33,34,41,42,43,44$. Prognosis baik karena pasien tidak memiliki riwayat penyakit sistemik, pasien memiliki motivasi yang tinggi dan sangat kooperatif dengan rencana perawatan yang akan dilakukan. Etiologi pada kasus ini disebabkan karena iritasi plak, faktor predisposisi berupa kalkulus supragingiva dan subgingiva serta adanya traumatik oklusi pada gigi $31,32,41,42$ dengan plat GTSL 11.

\section{METODE PENELITIAN}

Pada pemeriksaan gigi $31,32,33,34,41,42,43,44 \quad$ terlihat kedalaman poket $>5 \mathrm{~mm}$, terdapat resesi gingiva dan gigi goyang 03 . Perawatan pertama yang dilakukan yaitu skeling rahang atas dan rahang bawah, dilakukan perlahan-lahan dengan menahan gigi tersebut (Gambar 3). Dua minggu setelah dilakukan skeling, kemudian dilanjutkan dengan pembedahan flap periodontal dengan insisi horizontal dan vertical pada bagian distal gigi 34 dan 44. (Gambar 4). Pasien dirawat dengan membuka flap untuk melakukan debridement dibawah anestesi lokal. Semua kalkulus subgingiva dihilangkan dengan kuretase. Flap yang telah dibuat kemudian ditraksi dengan menggunakan elevator periodontal (Gambar 5). Kemudian dilakukan kuretase dan root planning pada gigi anterior rahang bawah (Gambar 6). Setelah dilakukan kuretase dan root planning, serta dipastikan sudah tidak terdapat lagi kalkulus baik di supragingiva maupun subgingiva, maka dilakukan irigasi dengan larutan $\mathrm{NaCl}$. Jaringan bekas insisi kemudian dijahit dan menutup daerah operasi dengan menggunakan pack periodontal (Gambar 7 dan gambar 8). Pada kunjungan 7 hari post op dilakukan splinting berupa wire 
komposit untuk memberikan dilepaskan dan digantikan dengan pertahanan terhadap gigi-gigi yang splint komposit interdental. Kemudian telah dirawat. Namun, pada kunjungan dilakukan perawatan berupa occlusal 14 hari post op pasien mengeluhkan adjustment pada gigi $31,32,41,42$ kurang nyaman dengan wirenya, untuk menghilangkan kontak prematur karena sangat mengganggu saat dari plat GTSL 11.

berbicara oleh karena itu splint wire

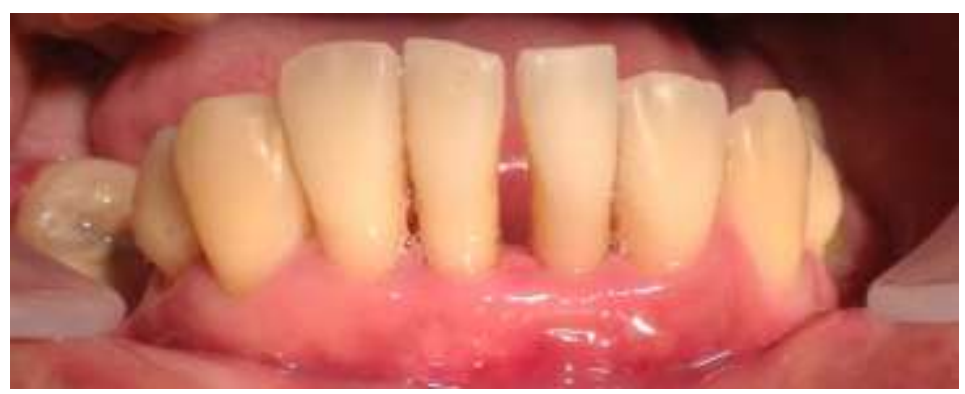

Gambar 3. Post Skeling

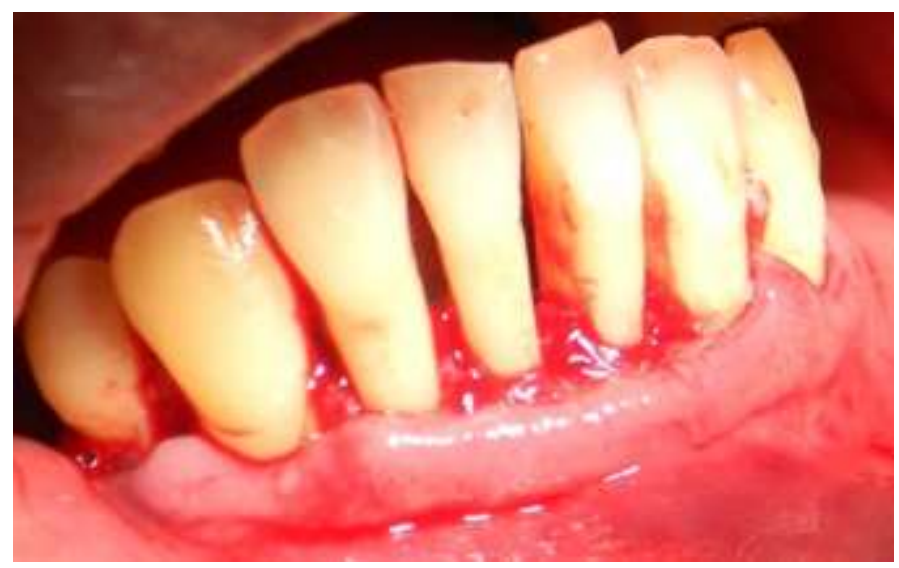

Gambar 4. Setelah dilakukan insisi

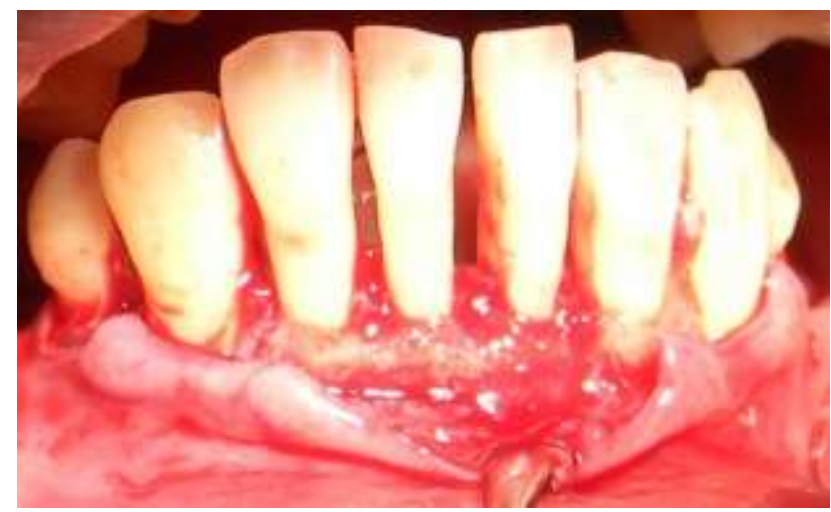

Gambar 5. Flap ditraksi dengan menggunakan elevator periodontal 


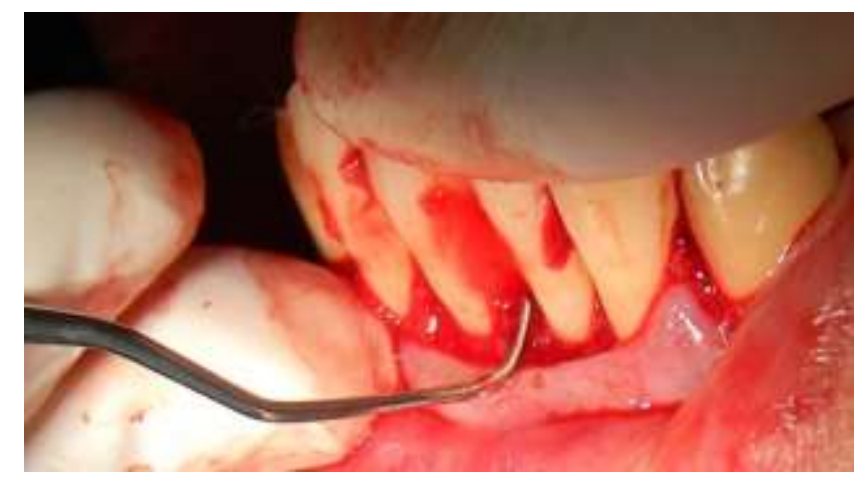

Gambar 6. Kuretase

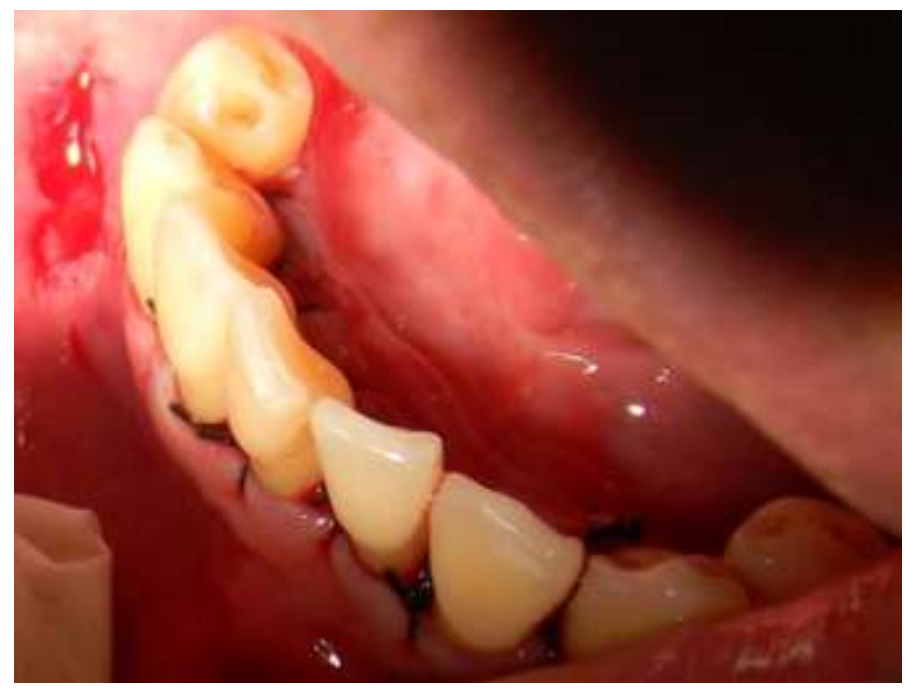

Gambar 7. Penjahitan dilakukan pada interdental

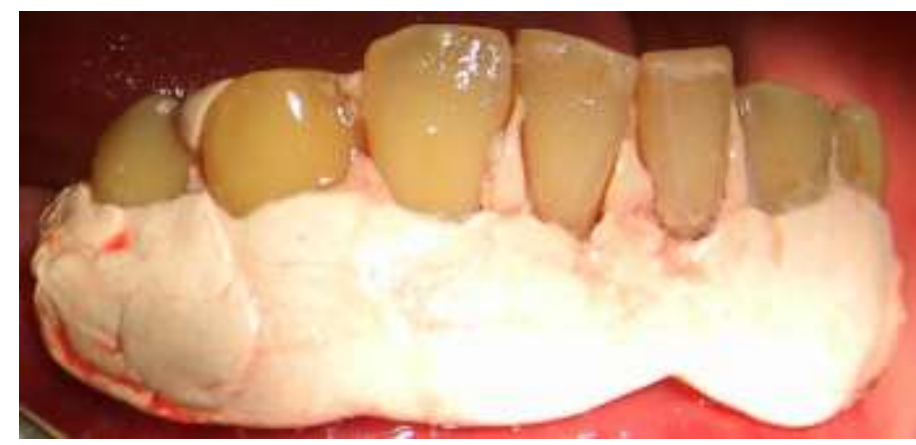

Gambar 8. Pemasangan pack periodontal

HASIL PENELITIAN

Pasien kemudian kontrol setelah 3 minggu untuk melepaskan benang jahitan. Terlihat dengan jelas jaringan gingiva yang normal dengan perlekatan gingiva yang baik. Kegoyangan gigi juga berkurang menjadi ${ }^{\circ} 1$. Kontrol post operasi (Gambar 9) dari hari ke hari terlihat dengan jelas perubahan-perubahan yang terjadi mulai dari warna gingiva yang sudah normal tidak hiperemi dan terlihat perlekatan margin gingiva yang baik ke permukaan gigi. Gambar 10 
terlihat jelas perbedaan sebelum dan setelah dilakukan perawatan.

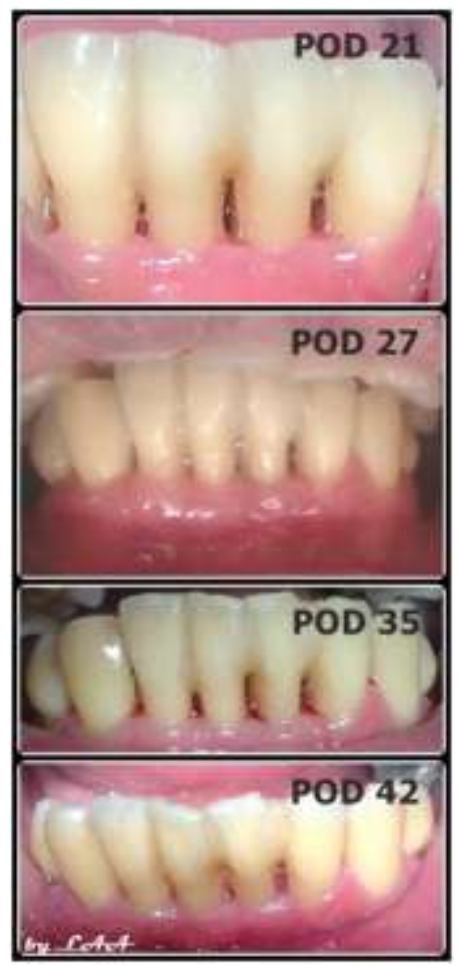

Gambar 9. Kontrol post operasi

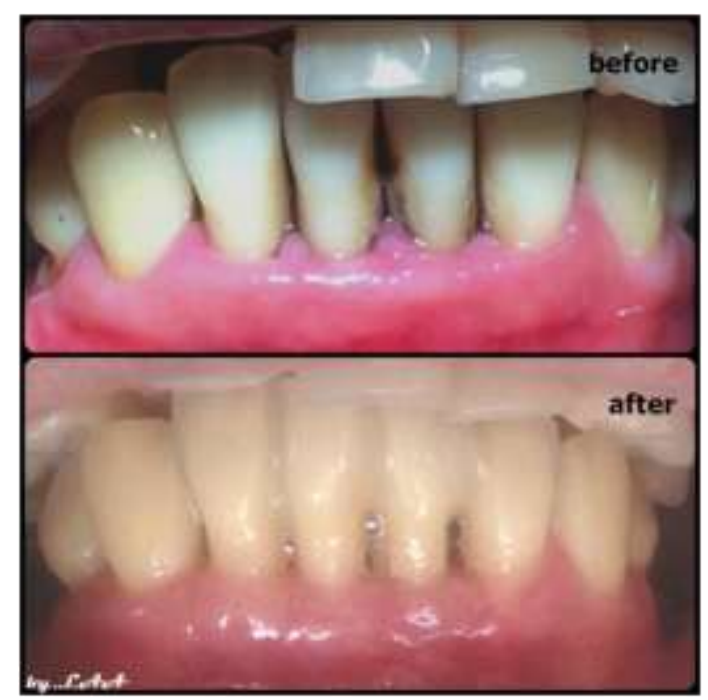

Gambar 10. Sebelum dan setelah perawatan

\section{KESIMPULAN}

Periodontitis kronis bersifat multifaktor. Penyakit ini dicetuskan oleh bakteri plak dan progresi serta keparahannya dipengaruhi oleh faktor lokal, faktor sistemik dan kondisikondisi lingkungan ataupun perilaku. Pencegahan periodontitis kronis mempersyaratkan tindakan mencegah pembentukan akumulasi bakteri plak (biofilm). Adapun perawatannya merupakan kerja sama antara klinisi dan pasien dalam mempertahankan kesehatan jaringan periodonsium. Keberhasilan perawatan tergantung pada berhentinya proses kerusakan jaringan dengan cara mengurangi hingga menghilangkan faktor penyebab serta perubahan kondisi mikroba. Hal tersebut dapat dicapai dengan salah satu alternatif perawatan yang dapat dilakukan pada kasus periodontitis kronis berupa perawatan bedah flap periodontal tanpa membutuhkan material regeneratif. Asalkan kondisi oral hygiene tetap dijaga dan dikontrol setelah perawatan dilakukan untuk mempertahankan hasil yang telah didapatkan. Laporan kasus ini menekankan akan pentingnya melakukan pemeriksaan gigi secara rutin untuk mencegah lebih awal terjadinya penyakit periodontitis kronis.

\section{DAFTAR PUSTAKA}

Suwandi Trijani. The Initial Treatment of Mobile Teeth Closure Diastema in Chronic Adult Periodontitis. PDGI Jour 2010;59:105-109. 
Novak MJ. Novak KF. Chronic periodontitis. In: Dolan J, editor. Carranza's Clinical Periodontology. $11^{\text {th }}$ Ed. China: Saunders Elsevier; 2011. P.1604.

Kinane DF. Lindhe J. Trombelli L. Chronic periodontitis. In: Lindhe $\mathrm{J}$, Lang NP, Karring T, editors. Clinical Periodontology and Implant Dentistry. $5^{\text {th }}$ Ed. Oxford: Blackwell Munksgaard; 2008. P.420-6.

Carranza FA, Camargo PM, Takei $\mathrm{HH}$. Bone loss and patterns of bone destruction.In: Dolan J, editor. Carranza's Clinical Periodontology. $11^{\text {th }}$ Ed. China: Saunders Elsevier; 2011. P. 1404.
Hall Wb. Prognosis. In: Hall WB, editor. Critical Decision in Periodontology. $4^{\text {th }}$ Ed. London: BC Dekker Inc.; 2003. P. 72-3.

Hall Wb. Sequence of treatment. In: Hall WB, editor. Critical Decision in Periodontology. $4^{\text {th }}$ Ed. London: BC Dekker Inc.; 2003. P. 72-3.

Olivia Sandra, Natalia, Hartono Felix. Papilla Preservation Flap as Aesthetics Consideration in Periodontal Flap Surgery. J Dent Ind 2012;19:76.

Mueller HP. Periodontology: the Essential. Germany: Druckhaus Gutz. 2005. P. 56. 